19 Revue d'histoire du XIXe siècle

Société d'histoire de la révolution de 1848 et des

révolutions du XIXe siècle

$15 \mid 1997$

1818. Nouveaux regards

\title{
1848 : notes sur les révolutions en Europe. La place des femmes contestée
}

Michèle Riot-Sarcey

\section{OpenEdition}

Journals

Electronic version

URL: http://journals.openedition.org/rh19/122

DOI: $10.4000 /$ rh19.122

ISSN: $1777-5329$

Publisher

La Société de 1848

\section{Printed version}

Date of publication: 1 December 1997

ISSN: 1265-1354

\section{Electronic reference}

Michèle Riot-Sarcey, «1848: notes sur les révolutions en Europe. La place des femmes contestée » Revue d'histoire du XIXe siècle [Online], 15 | 1997, Online since 10 September 2008, connection on 01 May 2019. URL : http://journals.openedition.org/rh19/122 ; DOI : 10.4000/rh19.122

This text was automatically generated on 1 May 2019.

Tous droits réservés 


\section{8 : notes sur les révolutions en Europe. La place des femmes contestée}

Michèle Riot-Sarcey

\section{ABSTRACTS}

No abstract available by now

Pas de résumé disponible actuellement

INDEX

Mots-clés: 1848, Femmes 